\title{
Chronic fatigue and minor psychiatric morbidity after viral meningitis: a controlled study
}

\author{
Matthew Hotopf, Norman Noah, Simon Wessely
}

\begin{abstract}
Objective-To test the hypotheses that patients exposed to viral meningitis would be at an increased risk of developing chronic fatigue syndrome and would have an excess of neurological symptoms and physical impairment.
\end{abstract}

Methods-Eighty three patients were followed up 6-24 months after viral meningitis and a postal questionnaire was used to compare outcome with 76 controls who had had non-enteroviral, non-CNS viral infections.

Results-For the 159 patients and controls the prevalence of chronic fatigue syndrome was $12 \cdot 6 \%$, a rate higher than previously reported from primary care attenders, suggesting that moderate to severe viral infections may play a part in the aetiology of some fatigue states. Those with a history of meningitis showed a slight, non-significant increase in prevalence of chronic fatigue syndrome (OR 1.4; 95\% CI 0.5-3.6) which disappeared when logistic regression analysis was used to correct for age, sex, and duration of follow up (OR 1.0; 95\% CI 0.3-2.8). Controls showed marginally higher psychiatric morbidity measured on the general health questionnaire-12 (adjusted OR 0.6; 95\% CI 0.3-1·3). Both groups had similar rates of neurological symptoms and physical impairment. The best predictor of chronic fatigue was a prolonged duration of time off work after the illness (OR 4.93, 95\% CI 1.3-18.8). The best predictor of severe chronic fatigue syndrome diagnosed by Center for Disease Control criteria was past psychiatric illness (OR $7 \cdot 82,95 \%$ CI $1 \cdot 8-34 \cdot 3)$. Duration of viral illness, as defined by days in hospital, did not predict chronic fatigue syndrome. Conclusions-(1) The prevalence of chronic fatigue syndrome is higher than expected for the range of viral illnesses examined; (2) enteroviral infection is unlikely to be a specific risk factor for its development; (3) onset of chronic fatigue syndrome after a viral infection is predicted by psychiatric morbidity and prolonged convalescence, rather than by the severity of the viral illness itself.

\section{(F Neurol Neurosurg Psychiatry 1996;60:504-509)}

Keywords: chronic fatigue syndrome; viral meningitis; psychiatric morbidity
Viral meningitis is usually considered to be a benign illness. It is most commonly caused now by enteroviruses, as mumps has decreased in incidence. ${ }^{1}$ Enteroviral infection has been suggested as a cause of fatigue and chronic fatigue syndrome, sometimes called postviral fatigue syndrome or myalgic encephalomyelitis (ME). ${ }^{2}$ A range of serological and viral markers of infection in patients has been examined in case-control studies. Early results suggested a relation between these markers of infection and current symptoms. ${ }^{2-7}$ These studies have been criticised $^{8}$ for their use of inappropriate control groups, and selection and ascertainment biases. More recent studies, which have overcome these methodological problems, suggest that the relation is less compelling than previously thought, ${ }^{9-13}$ although one well conducted study found evidence for a relation. ${ }^{14}$

One problem is the difficulty of defining exposure given the frequency of enteroviral infections in the community. We hypothesised that if enteroviral infection is a true risk factor for chronic fatigue syndrome, then this effect will be strongest in a sample of patients exposed to enteroviral infection of the CNS. Patients with viral meningitis represent such a sample: in the United Kingdom enteroviruses are the commonest cause of viral meningitis. ${ }^{15}$ If enteroviruses cause chronic fatigue syndrome we would expect patients recovering from viral meningitis to be at increased risk of abnormal fatigue. Viral meningitis is also said to be benign and without neurological sequelae and this was also examined in this study.

There are two large studies that followed up patients with viral meningitis. Lepow et $a l^{16}$ in an uncontrolled study found that two thirds of patients were at risk of fatigue, headaches, and clumsiness three months after the illness, but the impression was of recovery at one year, although follow up was incomplete. Muller et $a l^{17}$ traced 238 patients with aseptic meningitis and followed them up for two to 12 years. They could detect no difference between their mental health and that of healthy controls. These two studies did not aim to examine patients specifically for fatigue; nor did they use standardised assessments of symptoms.

The aims of this study were: (a) to examine whether patients with viral meningitis are at greater risk of subsequent chronic fatigue syndrome, psychiatric morbidity, and neurological complications than a control group of patients who had non-enteroviral, non-CNS, viral illnesses; $(b)$ to attempt to find predictors of fatigue and psychological symptoms. 


\section{Methods}

CASE SELECTION

Cases were identified from four virology laboratories and from the records of a hospital specialising in infectious diseases. These represented a mix of urban and rural populations. In the virology laboratories records of samples of CSF in the routine day books over the previous two years (July 1991-June 1993) were used to identify patients, whose hospital case notes were then obtained and examined. For cases at the infectious diseases hospital the disease cards (which document by disease each admission to the hospital) were used to identify cases of viral meningitis and the relevant case notes were then checked.

In all cases the following inclusion criteria were met: age 16-65; a clinical diagnosis of acute onset meningitis (characterised by pyrexia, headache, photophobia, and neck stiffness) leading to admission to hospital; spontaneous resolution of symptoms; evidence of lymphocytic meningitis as defined by lymphocytes in the CSF $\left(>8\right.$ per $\left.\mathrm{cm}^{3}\right)$. Cases were excluded if there was any evidence of a bacterial or other non-viral cause of the meningitis from microscopy and culture of the CSF. Further exclusion criteria included serious medical illnesses, which would be a potential cause of fatigue, and patients with a history of psychosis, substance misuse, or eating disorder. Other psychiatric disorders were not excluded. Cases with illness that had appeared in the context of recent travel outside Europe and North America were also excluded. Finally, cases were excluded if there was a clinical suspicion or definite confirmation of HIV infection.

\section{CONTROL SELECTION}

Controls were identified from one virology laboratory and the infectious diseases hospital. Those identified from the laboratory were proved cases of self limiting viral infections which the laboratory had identified from samples other than chronic fatigue syndrome. From this information hospital casenotes or general practice records were examined. Controls were identified from the infectious diseases hospital using the disease cards and casenotes. Inclusion criteria were of self limiting viral illness which had led to admission to hospital or consultation with a general practitioner in the past two years in patients aged 16-65 years. Exclusion criteria were as for the patients. Viral illnesses characterised by persistent pathology - such as hepatitis B, enterovi- ral infections, and infectious mononucleosis (which has been shown to be a risk factor for fatigue $^{18}$ ) were also excluded. Controls with any evidence of "meningism" (nuchal rigidity and photophobia) or a history of lumbar puncture during the acute illness were excluded.

\section{CASE NOTE INFORMATION}

For all subjects, case notes or hospital discharge summaries were examined to gather baseline sociodemographic information and details regarding current and past physical and psychiatric illness. Information on the nature of the illness leading to admission to hospital was also collected on a checklist of symptoms and signs. Investigations performed in hospital were recorded as well as any information on the clinical state of the patient at discharge.

\section{POSTAL SURVEY}

A questionnaire was designed to elicit sociodemographic details and information regarding medical and psychiatric history and service use. Current psychiatric health was measured using the general health questionnaire-12 (GHQ-12) ${ }^{19}$ and the Beck depression inventory. ${ }^{20}$ Fatigue was measured on a validated questionnaire used in several studies of chronic fatigue and chronic fatigue syndrome. ${ }^{21}$ Somatic symptoms were identified on a checklist of 32 symptoms. Finally, functional impairment and quality of life were assessed on the medical outcome survey short form (SF-36) scored according to predetermined thresholds. ${ }^{22}$ Table 1 gives the definitions of the different fatigue syndromes. Chronic fatigue syndrome is defined according to the Green College criteria ${ }^{23}$ or to the Center for Disease Control (CDC) criteria (chronic fatigue syndrome +$).{ }^{24}$

\section{Results}

Of 255 eligible patients, $159(62 \%)$ responded. Of the remainder, 49 had changed address and could not be traced. If these were removed from the sample the response rate was $77 \%$. The remaining non-responders either failed to return a questionnaire despite reminders or returned the questionnaire uncompleted. There were no differences between responders and non-responders in terms of age and sex. A similar proportion of persons in each group responded. Of the responders, there were 76 controls and 83 patients. Table 2 gives a description of the diagnoses of control subjects.
Table 1 Definition of fatigue states

\begin{tabular}{|c|c|c|}
\hline Chronic fatigue & $\begin{array}{l}\text { Chronic fatigue syndrome } \\
\text { (Green College) }\end{array}$ & $\begin{array}{l}\text { Chronic fatigue syndrome }+ \\
\text { (CDC) }\end{array}$ \\
\hline $\begin{array}{l}\text { - Score }>4 \text { on fatigue } \\
\text { questionnaire } \\
\text { - Present }>6 \text { months } \\
\text { - No medical illness or major } \\
\text { mental illness to explain fatigue }\end{array}$ & $\begin{array}{l}\text { - As for chronic fatigue } \\
\text { Plus } \\
\text {-Present } 50 \% \text { of the time } \\
\text { - Causes functional impairment } \\
\text { - Both mental and physical } \\
\text { symptoms of fatigue }\end{array}$ & $\begin{array}{l}\text { - As for chronic fatigue } \\
\text { syndrome } \\
\text { Plus } \\
\text {-Four of the following } \\
\text { symptoms: new headache; } \\
\text { post exertional malaise; } \\
\text { memory/concentration } \\
\text { difficulties myalgia; sore } \\
\text { throat; lymphadenopathy; } \\
\text { polyarthralgia, and } \\
\text { unrefreshing sleep }\end{array}$ \\
\hline
\end{tabular}

Table 2 Diagnoses for the 76 controls

\begin{tabular}{lc}
\hline Diagnosis & No (\%) \\
\hline Hepatitis A & $25(32 \cdot 8)$ \\
Epstein-Barr virus hepatitis & $2(2 \cdot 6 \%)$ \\
Adenovirus & $6(7 \cdot 9)$ \\
Measles & $1(1 \cdot 3)$ \\
Chickenpox & $20(26 \cdot 3)$ \\
Influenza & $4(5 \cdot 3)$ \\
Unknown: URTI & $13(17 \cdot 1)$ \\
Unknown: rash & $2(2 \cdot 6)$ \\
Unknown: gastroenteritis & $2(2 \cdot 6)$ \\
\hline
\end{tabular}


DEMOGRAPHIC CHARACTERISTICS

There were no significant differences between those exposed to viral meningitis and controls in terms of age (32 $v 31$ years), home ownership ( $56 \% v 51 \%$ own home), duration of stay in hospital (5.9 days $v 4.9$ days), and marital status ( $55 \%$ v $45 \%$ married or cohabiting). Cases of viral meningitis were more likely to be female $\left(64 \% v 46 \%, \chi^{2}=5.08,1 \mathrm{df}, \mathrm{P}=\right.$ 0.02 ), and to have taken more time off work after the illness (49 days $v 30$ days, $U=2115$, $z=-2 \cdot 13, P=0.03$ (Mann-Whitney $U$ test)). The duration of follow up was also longer in patients who were followed up for a mean of 18 months compared with 13 for the controls $(U=1965, \mathrm{z}=-4 \cdot 00, \mathrm{P}=0.0001)$. The duration of follow up and sex differences are likely to confound the results of other outcome variables. Nine of the control subjects were not admitted to hospital but were treated by their general practitioner.

\section{OUTCOME VARIABLES}

\section{Fatigue and psychiatric outcome}

Table 3 shows the outcome for cases and controls. Cases of viral meningitis were not at increased risk of chronic fatigue, chronic fatigue syndrome, or chronic fatigue syndrome + . There was no increase in risk of depression as measured by the BDI, or emotional distress on the GHQ-12. To control for the potential confounding variables of age, sex, and duration of follow up, a forced entry logistic regression analysis was performed. Again no differences could be detected in outcome between cases and controls. These outcomes were no different if the controls who had not been admitted to hospital were excluded from the analysis.

Physical symptoms and impairments Cases and controls did not differ in their score on the checklist of 32 possible symptoms (mean number for cases 7.4 and 9.0 for controls, $t=1 \cdot 10,154 \mathrm{df}, \mathrm{P}=0 \cdot 27$ ). To assess whether the cases were at greater risk of neurological symptoms total scores on the eight neurological symptoms (headaches, tremor, tingling in the arms and tingling in the legs, double vision, light headedness, increased sensitivity to noise, and increased sensitivity to light) were compared. Again no excess of symptomatology was found $(1.8 v 2.1$ neurological symptoms for cases and controls respectively: $t=1.41, \quad 155 \mathrm{df}, \quad P=0.16$ ). Impairment measured on the six subscales of the SF-36 showed no differences between cases and controls in any area of functioning (table 4). This finding was not changed when odds ratios were adjusted for age, sex, and duration of follow up using logistic regression analysis.

FACTORS PREDICTIVE OF CHRONIC FATIGUE, CHRONIC FATIGUE SYNDROME, AND CHRONIC FATIGUE SYNDROME +

We went on to examine the features of those we identified with chronic fatigue, chronic fatigue syndrome, and chronic fatigue syndrome + . These three conditions represent gradations of severity along the range of fatigue so it is not surprising that there were more cases of chronic fatigue (36) than of chronic fatigue syndrome (20) and chronic fatigue syndrome $+(11)$. For all three diagnoses there were no differences between cases and healthy controls in terms of age, sex distribution, duration of follow up, or duration of stay in hospital. Table 5 summarises the main differences between those with chronic fatigue syndrome and those who were well at follow up. These results are similar for chronic fatigue and chronic fatigue syndrome + . More cases had used services for emotional

Table 3 Outcome for cases of viral meningitis and other viral illness controls

\begin{tabular}{|c|c|c|c|c|c|c|c|c|}
\hline & $\begin{array}{l}\text { Cases } \\
(n=83)\end{array}$ & $\begin{array}{l}\text { Controls } \\
(n=76)\end{array}$ & $\chi^{2}$ & Pvalue & $O R$ & $95 \% C I$ & $\operatorname{adj} O R$ & $\begin{array}{l}95 \% \text { CI for } \\
\text { adj OR }\end{array}$ \\
\hline Chronic fatigue & $\begin{array}{l}21 \\
(25 \%)\end{array}$ & $\begin{array}{l}15 \\
(20 \%)\end{array}$ & 0.62 & 0.43 & $1 \cdot 35$ & $0.6-2 \cdot 9$ & $1 \cdot 13$ & $0.5-2 \cdot 6$ \\
\hline Chronic fatigue syndrome & $\begin{array}{l}12 \\
(14 \%)\end{array}$ & $\begin{array}{c}8 \\
(10 \%)\end{array}$ & $0 \cdot 47$ & $0 \cdot 49$ & $1 \cdot 39$ & $0 \cdot 5-3 \cdot 6$ & 0.96 & $0 \cdot 3-2 \cdot 8$ \\
\hline Chronic fatigue syndrome + & $\begin{array}{c}8 \\
(10 \%)\end{array}$ & $\begin{array}{l}3 \\
(4 \%)\end{array}$ & 1.93 & $0 \cdot 16$ & $2 \cdot 55$ & $0 \cdot 6-10 \cdot 0$ & $1 \cdot 78$ & $0 \cdot 4-8 \cdot 0$ \\
\hline $\begin{array}{l}\text { Case on GHQ } \\
(3 / 4)\end{array}$ & $\begin{array}{l}39 \\
(48 \%)\end{array}$ & $\begin{array}{l}37 \\
(51 \%)\end{array}$ & $0 \cdot 15$ & $0 \cdot 15$ & 0.88 & $0 \cdot 4-1 \cdot 6$ & $0 \cdot 64$ & $0.31-1 \cdot 34$ \\
\hline $\begin{array}{c}\text { Case on BDI } \\
(12 / 13)\end{array}$ & 11 & $\begin{array}{l}17 \\
(24 \%)\end{array}$ & $2 \cdot 82$ & 0.09 & 0.49 & $0 \cdot 4-2 \cdot 3$ & $0 \cdot 78$ & $0 \cdot 14-1 \cdot 01$ \\
\hline
\end{tabular}

$\mathrm{OR}=$ Odds ratio; adj $\mathrm{OR}=$ adjusted odds ratio.

Table 4 Impairment on SF-36 at follow up

\begin{tabular}{|c|c|c|c|c|c|c|c|c|}
\hline & $\begin{array}{l}\text { Cases } \\
(n=83)\end{array}$ & $\begin{array}{l}\text { Control } \\
(n=76)\end{array}$ & $\chi^{2}$ & Pvalue & $O R$ & $95 \% C I$ & $\operatorname{adj} O R$ & $\begin{array}{l}95 \% \text { CI for } \\
\text { adj OR }\end{array}$ \\
\hline $\begin{array}{l}\text { Psychological } \\
\text { impairment }\end{array}$ & $\begin{array}{l}31 \\
(38 \%)\end{array}$ & $\begin{array}{l}30 \\
(41 \%)\end{array}$ & $0 \cdot 17$ & 0.67 & 0.87 & $0 \cdot 5-1 \cdot 7$ & 0.79 & $0.4-1.7$ \\
\hline Pain & $\begin{array}{l}24 \\
(29 \%)\end{array}$ & $\begin{array}{l}20 \\
(28 \%)\end{array}$ & 0.04 & 0.83 & $1 \cdot 08$ & $0 \cdot 5-2 \cdot 2$ & $1 \cdot 02$ & $0 \cdot 5-2 \cdot 2$ \\
\hline Perception of illness & $\begin{array}{l}43 \\
(54 \%)\end{array}$ & $\begin{array}{l}39 \\
(55 \%)\end{array}$ & 0.02 & $0 \cdot 88$ & 0.95 & $0 \cdot 5-1 \cdot 8$ & $1 \cdot 20$ & $0 \cdot 6-2 \cdot 5$ \\
\hline Physical impairment & $\begin{array}{l}45 \\
(55 \%)\end{array}$ & $\begin{array}{l}41 \\
(57 \%)\end{array}$ & 0.06 & $0 \cdot 79$ & 0.92 & $0 \cdot 1-1 \cdot 7$ & $1 \cdot 14$ & $0.5-2 \cdot 4$ \\
\hline $\begin{array}{l}\text { Role } \\
\text { function } \\
\text { impairment }\end{array}$ & $\begin{array}{l}21 \\
(26 \%)\end{array}$ & $\begin{array}{l}15 \\
(21 \%)\end{array}$ & 0.48 & 0.49 & $1 \cdot 31$ & $0 \cdot 6-2 \cdot 8$ & 1.68 & $0 \cdot 7-4 \cdot 0$ \\
\hline Social impairment & $\begin{array}{c}4 \\
(5 \%)\end{array}$ & $\stackrel{9}{(11 \%)}$ & $2 \cdot 7$ & $0 \cdot 1$ & $0 \cdot 37$ & $0 \cdot 1-1 \cdot 3$ & $0 \cdot 28$ & $0 \cdot 1-1 \cdot 1$ \\
\hline
\end{tabular}

OR = Odds ratio; adj $\mathrm{OR}=$ adjusted odds ratio 
Table 5 Characteristics of patients with chronic fatigue syndrome

\begin{tabular}{|c|c|c|c|c|c|}
\hline & $\begin{array}{l}\text { Chronic } \\
\text { fatigue } \\
\text { syndrome } \\
(n=20)\end{array}$ & $\begin{array}{l}\text { Non-chronic } \\
\text { fatigue } \\
\text { syndrome } \\
(n=139)\end{array}$ & Statistic & P value & $O R(95 \% C I)$ \\
\hline $\begin{array}{l}\text { Age (y (SD)) } \\
\text { Females (\%) }\end{array}$ & $\begin{array}{l}34 \cdot 1(11 \cdot 1) \\
13(65)\end{array}$ & $\begin{array}{l}31 \cdot 8(10 \cdot 4) \\
74(54)\end{array}$ & \multirow{2}{*}{$\begin{array}{l}{ }^{\star} \mathrm{z}=-0.76 \\
\chi^{2}=0.85 \\
1 \mathrm{df} \\
\star^{\star} \mathrm{z}=-0.5\end{array}$} & $\begin{array}{l}0 \cdot 44 \\
0 \cdot 36\end{array}$ & \multirow[t]{4}{*}{$\begin{array}{c}1 \cdot 58 \\
(0 \cdot 6-4 \cdot 2)\end{array}$} \\
\hline $\begin{array}{l}\text { Duration of stay in hospital } \\
\text { (days (SD)) }\end{array}$ & $5 \cdot 4(3.5)$ & $5 \cdot 4(5 \cdot 1)$ & & 0.64 & \\
\hline $\begin{array}{l}\text { Time taken off work (days } \\
\text { (SD)) }\end{array}$ & $62 \cdot 6(99 \cdot 1)$ & $37 \cdot 3(63 \cdot 4)$ & ${ }^{\star} \mathrm{z}=-1 \cdot 42$ & $0 \cdot 15$ & \\
\hline $\begin{array}{l}\text { Duration of follow up } \\
\text { (months (SD)) }\end{array}$ & $17 \cdot 2(6 \cdot 3)$ & $15 \cdot 5(7 \cdot 7)$ & ${ }^{\star} \mathrm{z}=-1 \cdot 14$ & $0 \cdot 25$ & \\
\hline Psychiatric history (\%) & $11(55)$ & $29(21)$ & $\begin{array}{l}\chi^{2}=10 \cdot 5 \\
1 \mathrm{df}\end{array}$ & 0.001 & \multirow{3}{*}{$\begin{array}{c}3 \cdot 05 \\
(1 \cdot 2-8 \cdot 1) \\
3 \cdot 77 \\
(1 \cdot 4-10 \cdot 4) \\
5 \cdot 00 \\
(1 \cdot 6-15 \cdot 7)\end{array}$} \\
\hline Depression on BDI (\%) & $9(35)$ & $20(13)$ & $\begin{array}{l}\chi^{2}=7 \cdot 24 \\
1 \mathrm{df}\end{array}$ & 0.007 & \\
\hline Distress on GHQ-12 (\%) & $16(80)$ & $60(44)$ & $\begin{array}{l}\chi^{2}=8 \cdot 81 \\
1 \mathrm{df}\end{array}$ & 0.003 & \\
\hline
\end{tabular}

^Mann-Whitney $U$ test.

Table 6 Adjusted odds ratios after logistic regression analysis to account for potential confounding variables, age, sex, and duration of follow up

\begin{tabular}{llll}
\hline & Chronic fatigue & $\begin{array}{l}\text { Chronic fatigue } \\
\text { syndrome }\end{array}$ & $\begin{array}{l}\text { Chronic fatigue } \\
\text { syndrome }+\end{array}$ \\
\hline Psychiatric history & $\mathrm{P}=0.55$ & $\mathrm{P}=0.02$ & $\mathrm{P}=0.006$ \\
& $\mathrm{OR}=1 \cdot 33$ & $\mathrm{OR}=3 \cdot 58$ & $\mathrm{OR}=7 \cdot 82$ \\
& $(0 \cdot 5-3 \cdot 4)$ & $(1 \cdot 2-10.6)$ & $\mathrm{P}=0 \cdot 12$ \\
Prolonged convalescence & $\mathrm{P}=0.002$ & $\mathrm{P}=0.02$ & $\mathrm{OR}=3 \cdot 8$ \\
& $\mathrm{OR}=4 \cdot 85$ & $(1 \cdot 3-18 \cdot 8)$ & $(0 \cdot 7-20 \cdot 9)$ \\
\hline
\end{tabular}

Values in parentheses are $95 \% \mathrm{CI}$.

problems and this relation became stronger as the severity of fatigue increased. Those with chronic fatigue and chronic fatigue syndrome had had a longer convalescence than those without fatigue states, but this difference did not maintain statistical significance in those with chronic fatigue syndrome + . Finally, those with fatigue states were more likely to be in psychological distress as measured on the GHQ-12 and to have depression as measured on the BDI.

\section{LOGISTIC REGRESSION}

To disentangle the potentially confounding variables of sex, duration of follow up, age, previous service use for emotional problems, and prolonged time off work after viral illness, a forced entry logistic regression analysis was performed. Prolonged time off work was coded as above and below median (21 days) taken off work after the viral illness. This allowed odds ratios (ORs) for the risk of fatigue states if an individual had had a psychiatric history or prolonged convalescence. Psychiatric history was no longer a statistically significant association with chronic fatigue, but was associated with chronic fatigue syndrome and chronic fatigue syndrome + . Prolonged convalescence was associated with chronic fatigue and chronic fatigue syndrome. Table 6 shows the adjusted ORs for these risk factors.

\section{Discussion}

There were three main findings in this study. Firstly, there were no statistically significant differences in outcome between the group who had viral meningitis compared with other viral infections. This suggests that there is little to support enterovirus infection as a specific risk factor for chronic fatigue syndrome. Secondly, the prevalence of chronic fatigue syndrome for the sample as a whole was considerably higher than that seen in primary care samples. Thirdly, the variables which best predict chronic fatigue syndrome at follow up are previous psychiatric morbidity and a prolonged convalescence.

These findings must be interpreted with care. This was a postal survey and a response rate of $77 \%$ leaves the results open to response bias, although no differences between responders and non-responders could be identified. The sample sizes used limit the statistical power of this study, and it is possible that small but significant differences between the two groups could have been missed. The rarity of adult viral meningitis makes it expensive and impractical to perform large scale prospective studies except after an epidemic.

There are also demographic differences between the two groups. There was an excess of women among the cases. We would have expected a higher rate of psychiatric disorder and fatigue among women so this potential confounder is likely to push the results toward a positive finding (an excess of fatigue among those exposed to viral meningitis). The other main difference was that the duration of follow up was longer in the viral meningitis group. This potential confounder should work in the opposite direction - that is, to increase the level of morbidity among the controls, who would be at an earlier stage of their convalescence. Our analyses suggest that these potential confounders are not powerful-there was no excess of fatigue among the female responders and the cases of fatigue identified were at a similar stage in their convalescence to those 
who were well. When these potential confounders were adjusted for by logistic regression analysis the lack of association between viral meningitis and subsequent fatigue remained.

The morbidity in the group as a whole was high. The prevalence of chronic fatigue syndrome was higher than that of previous surveys using the same instruments in primary care. For example, Wessely et $a l^{25}$ found that $9.9 \%$ and $1.3 \%$ of patients presenting to primary care with any viral infection had chronic fatigue or chronic fatigue syndrome respectively when followed up for six months after infection. These rates did not differ from those in the comparison group of patients presenting in primary care for other reasons. Our estimates for chronic fatigue syndrome $(12.6 \%)$ were considerably higher and we will examine possible reasons for this finding.

It may be that all the viral illnesses studied act directly to cause chronic fatigue syndrome. For example, there is now some evidence that hepatitis A may cause chronic fatigue. ${ }^{26}$ Unfortunately, without a control group admitted to hospital for non-viral illness it is impossible to test this hypothesis. However, there are two findings which are against this view: (1) there was no relation between the duration of initial admission to hospital, which may be used as a proxy measure of severity and fatigue; and (2) there was no relation between duration of follow up and fatigue. If exposure to severe viral infection on its own was responsible for these high rates of fatigue, those who were early in their convalescence would be expected to be most severely affected.

The increased rates of chronic fatigue and chronic fatigue syndrome could have been due to bias. With a response rate of $77 \%$, response bias is not a sufficient explanation, but may play a part, because those with fatigue may be more inclined to respond. Selection bias is an alternative explanation: the processes which led to admission of these patients to hospital may have contributed to their increased prevalence of chronic fatigue syndrome on follow up. Most patients with a viral infection are not admitted to hospital. This would apply to the infections seen among controls-for example, influenza and chickenpox. No studies are available on the admission rates for viral meningitis; however, there are degrees of severity for the illness, ranging from asymptomatic cases to the full syndrome of meningitis $^{15}$ and it is reasonable to suppose that a proportion of patients with viral meningitis do not consult or are not diagnosed as such. There is some support for this explanation from a prospective study of consulting behaviour after influenza infection. ${ }^{27}$ The attack rate for clinically evident infection with Asian influenza in the 1957 pandemic was increased almost threefold in high scorers on the Minnesota multiphasic personality inventory. This increase applied to clinically evident illness, not actual disease, as shown by a rise in antibody titres. This explanation is unlikely to fully account for the rates of chronic fatigue syndrome that we detected.
Assuming that the result of high levels of chronic fatigue syndrome are not due to bias or confounding, it is necessary to construct a model to bring our other findings together. Previous service use for emotional disorder and a prolonged period of time off work after the viral illness were associated with chronic fatigue syndrome. These variables are not independent. Logistic regression analysis showed that prolonged convalescence was a predictor for chronic fatigue and chronic fatigue syndrome. A history of previous consultation for psychiatric disorder predicted chronic fatigue syndrome and chronic fatigue syndrome + .

The finding that prolonged convalescence is a risk factor for chronic fatigue syndrome could be interpreted in two ways. Firstly, those who had a more serious viral illness would be more likely both to have a longer time off work and be more prone to chronic fatigue syndrome. This explanation must be balanced against the finding that the duration of stay in hospital, which is predominantly a doctor led assessment of severity, is no greater in those who later developed chronic fatigue syndrome. Secondly, duration of time off work is a measure of the patient's assessment of his or her symptoms and is more sensitive to the patient's illness behaviour, which may in turn be associated with chronic fatigue syndrome.

Could a better understanding of the pathogenesis of fatigue be gleaned from these findings? Prolonged time off work after a viral infection may be the principle mechanism of fatigue. Previous studies have found that bed rest or prolonged convalescence is a predictor of fatigue and subjective symptoms in infectious mononucleosis ${ }^{18}{ }^{28}$ and postvaccinial (yellow fever) illness. ${ }^{29}$ Further, there is evidence to suggest that poor prognosis in established chronic fatigue syndrome may relate to limiting exercise and changing or leaving employment. ${ }^{30}$ The deconditioning caused by such changes may be responsible for fatigue.

The relation between psychiatric morbidity and chronic fatigue syndrome is well established ${ }^{8}$ and in a prospective study one of the most powerful predictors of chronic fatigue and chronic fatigue syndrome after a viral infection was a high score on the GHQ-12. ${ }^{25}$ Psychiatric morbidity is also an indicator of poor prognosis of chronic fatigue syndrome. ${ }^{31-33}$ There is good evidence that psychiatric morbidity is an important determinant of functional recovery from other illnesses-for example, recovery after myocardial infarction ${ }^{34}$ and back pain..$^{35}$ Previous psychiatric morbidity might be a risk factor by leading to prolonged convalescence, or alternatively may act directly due to the considerable overlap between depression, anxiety, and fatigue.

Subsequent research should aim to compare recovery from a range of infectious and non-infectious physical illnesses with prospective information on psychiatric morbidity and changes in behaviour after acute illnesses. In this way it may be possible to predict those at risk of a poor outcome after physical illness, and to plan early interventions. 
MH was supported by a grant from the Wellcome Trust. We thank Professor Banatvala, Dr F Nicholson, Professor Carmichael, Dr S Sutherland, and Dr B Bannister for their advice and assistance in identifying subjects.

1 Noah N, Urquhart A. Virus meningitis and encephalitis in 1979. F Infect 1980;2:379-83.

2 Yousef G, Bell E, Mann G, et al. Chronic enterovirus infection in patients with postviral fatigue syndrome. Lancet 1988;i:146-50.

3 Calder BD, Warnock PJ. Coxsackie B infection in a Scottish general practice. $f R$ Coll Gen Pract 1984;34: 15-9.

4 Calder BD, Warnock PJ, McCartney RA, Bell EJ. Coxsackie $B$ viruses and the post viral fatigue syndrome: a prospective study in general practice. $f R$ Coll Gen Pract 1987;37:11-4.

5 Keighley BD, Bell EJ. Sporadic myalgic encephalomyelitis in a rural practice. $\mathcal{F} R$ Coll Gen Pract 1983;33:339-41.

6 Bell EJ, McCartney RA, Riding MH. Coxsackie B virus and myalgic encephalomyelitis. $f R$ Soc Med 1988;81: and myalgi.

7 Gow JW, Behan WM, Clements GB, Woodall C, Riding $M$, Behan PO. Enteroviral RNA sequences detected by polymerase chain reaction in muscles of patients with post viral fatigue syndrome. $B M \mathcal{F} 1991 ; 302: 692-6$.

8 Hotopf $M H$, Wessely SC. Viruses, neurosis and fatigue. $\mathcal{f}$ Psychosom Res 1994;38:499-514.

9 Miller NA, Carmichael HA, Calder BD, et al. Antibody to Coxsackie $B$ virus in diagnosing postviral fatigue syndrome. BMf 1991;302:140-3.

10 Lynch S, Seth R. Postviral fatigue syndrome and VP-1 antigen. Lancet 1989;2:1160-1.

11 Halpin D, Wessely S. VP-1 antigen in chronic fatigue syndrome. Lancet 1989;1:1028-9.

12 Gow JW, Behan WM, Simpson K, McGarry F, Keir S, Behan PO. Studies on enteroviruses in patients with chronic fatigue syndrome. Clin Infect Dis 1994;(suppl 1): chronic

13 Swanink C, Melchers W, van der Meer J, et al. Enteroviruses and the chronic fatigue syndrome. Clin Infect Dis 1994;19:860-4.

14 Clements GB, McGarry F, Nairn C, Galbraith DN. Detection of enterovirus specific RNA in serum: the relationship to chronic fatigue. $\mathcal{F}$ Med Virol 1995;45:156-61.

15 Jubelt B, Lipton HL. Enterovirus infection. In: McKendall $\mathrm{RR}$, ed. Handbook of clinical neurology. Amsterdam: Elsevier 1989.

16 Lepow ML, Coyne N, Thompson LB. A clinical epidemiologic and laboratory investigation of aseptic meningitis during the four year period 1955-1958: II the clinical disease and its sequelae. $N$ Engl $\mathcal{f}$ Med 1962;266: disease 93

17 Muller R, Nylander I, Larsson L, Widen L, Frankenhauser $M$. Sequelae of primary aseptic meningoencephalitis: a clinical, sociomedical, electroencephalographic and psychological study. Acta Psychiatr Scand 1958;(suppl 126): 1-115.

18 White PD, Grover SA, Kango HO, Thomas JM, Ames SJ, Clare AW. The validity and reliability of the fatigue syndrome that follows glandular fever. Psychol Med 1995; 25:917-24.

19 Goldberg D. The detection of psychiatric illness by questionnaire. London: Oxford University Press, 1972.

20 Beck AT, Ward CH, Mendelson M. An inventory for measuring depression. Arch Gen Psychiatry 1961;4:561-71.

21 Chalder T, Berelowitz C, Pawlikowska T. Development of a fatigue scale. $\mathcal{F}$ Psychosom Res 1993;37:147-54.

22 Stewart AD, Hays RD, Ware JE. The MOS short-form general health survey. Med Care 1988;26:724-32.

23 Ray WA, Fought RL, Decker MD. Psychoactive drugs and the risk of injurious motor vehicle crashes in elderly drivers. Am F Epidemiol 1992;136:873-83.

24 Fukuda $K$, Straus S, Hickie I, Sharpe $M$, Dobbins J, Komaroff $\mathrm{A}$. The chronic fatigue syndrome: a comprehensive approach to its definition and study. Ann Intern Med 1994;121:953-9.

25 Wessely S, Chalder T, Hirsch S, Palikowska T, Wallace P, Wright DJM. Post-infectious fatigue: prospective cohor study in primary care. Lancet 1995;345:1333-8.

26 Berelowitz GJ, Burgess AP, Thanabalasingham T, MurrayLyon IM, Wright DJM. Post-hepatitis syndrome revisited. Hepatitis 1996 (in press).

27 Cluff LE, Canter A, Imboden JB. Asian influenza: infection, disease and psychological factors. Arch Intern Med 1966;117:159-63.

28 Dalrymple W. Infectious mononucleosis: 2 . relation of bed rest and activity to prognosis. Postgrad Med 1961;35: 345-9.

29 Benjamin JE, Hoyt RC. Disability following postvaccinial (yellow fever) hepatitis. $\mathcal{F} A M A$ 1945;128:319-23.

30 Wilson A, Hickie I, Lloyd A, et al. Longitudinal study of outcome of chronic fatigue syndrome. $B M \mathcal{F} 1994 ; 308$. 756-9.

31 Sharpe M, Hawton K, Seagroatt V, Pasvol G. Follow up of patients presenting with fatigue to an infectious diseases clinic. BMF 1992;305:147-52.

32 Clark RR, Katon W, Russo J, Kith P, Sintay M, Buchwald D. Chronic fatigue: risk factors for symptom persistence in a $2 \frac{1}{2}$ year follow up study. Am $\mathcal{F}$ Med 1995;98: $187-95$.

33 Wilson A, Hickie I, Lloyd A, et al. Longitudinal study of outcome of chronic fatigue syndrome. $B M F$ 1994;308: 756-9.

34 Ladwig KH, Roll G, Breithardt G, Budde T, Borggrefe M. Post-infarction depression and incomplete recovery 6 months after acute myocardial infarction. Lancet 1994;343:20-3.

35 Burton K, Tillotson M, Main C, Hollis S. Psychosocial predictors of outcome in acute and sub-chronic low back trouble. Spine 1995;20:722-8. 